\title{
Erythrocyte sodium-lithium countertransport activity and total body insulin-mediated glucose disposal in normoalbuminuric normotensive Type 1 (insulin-dependent) diabetic patients
}

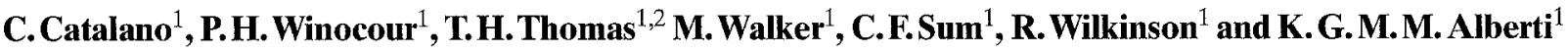 \\ Departments of ${ }^{1}$ Medicine and ${ }^{2}$ Clinical Biochemistry, The University of Newcastle upon Tyne, Newcastle upon Tyne, UK
}

\begin{abstract}
Summary. Insulin resistance in Type 1 (insulin-dependent) diabetes mellitus may be associated with raised erythrocyte sodium-lithium countertransport activity in patients with hypertension, or nephropathy, or both. However, in these circumstances it is difficult to separate the impact of hypertension, hyperlipidaemia and nephropathy on erythrocyte sodium-lithium countertransport from that of insulin resistance. We have therefore examined the relationship between insulin-mediated glucose disposal and erythrocyte sodiumlithium countertransport in 41 normotensive (mean blood pressure $120 / 74 \mathrm{~mm} \mathrm{Hg}$ ), normoalbuminuric (mean albumin excretion $6.2 \mu \mathrm{g} / \mathrm{min}$ ), normolipidaemic (mean serum cholesterol $4.3 \mathrm{mmol} / 1$ and mean serum triglycerides $1.0 \mathrm{mmol} / \mathrm{l}$ ) Type 1 diabetic patients. Erythrocyte sodium-lithium countertransport was on average $0.31 \mathrm{mmol} \mathrm{Li} \cdot \mathrm{h}^{-1} \cdot 1$ erythrocytes $^{-1}$ (range 0.07-0.69). Nine patients had values above $0.40 \mathrm{mmol} \mathrm{Li} \cdot \mathrm{h}^{-1} \cdot 1$ erythrocytes $^{-1}(0.51 \pm 0.10 \mathrm{mmol}$ $\mathrm{Li} \cdot \mathrm{h}^{-1} \cdot 1$ erythrocytes $\left.{ }^{-1}\right)$. The patients with high erythrocyte sodium-lithium countertransport were matched for age, sex, $\mathrm{BMI}, \mathrm{HbA}_{1}$ and duration of diabetes, with nine patients with normal erythrocyte sodium-lithium countertransport. Insulin-mediated glucose disposal was evaluated during the last hour of a euglycaemic clamp (insulin $0.015 \mathrm{U} \cdot \mathrm{kg}^{-1} \cdot \mathrm{h}^{-1}$;
\end{abstract}

blood glucose clamped at $7.0 \mathrm{mmol} / \mathrm{l}$ ). The free insulin levels were comparable between the patients with high and normal erythrocyte sodium-lithium countertransport (37.2 \pm $14.7 \mathrm{mU} / \mathrm{l}$ and $34.7 \pm 17.2 \mathrm{mU} / \mathrm{l}$ respectively). Insulin-mediated glucose disposal was on average $3.1 \pm 1.5$ (range $0.8-6.8$ ) $\mathrm{mg} \cdot \mathrm{kg}^{-1} \cdot \mathrm{min}^{-1}$. Erythrocyte sodium-lithium countertransport did not correlate with insulin-mediated glucose disposal in all 41 cases $\left(r_{s}=-0.14\right)$, but when the matched groups were compared, patients with raised erythrocyte sodiumlithium countertransport had lower insulin-mediated glucose disposal rates compared to those with normal erythrocyte sodium-lithium countertransport $(2.7 \pm 1.1$ vs $\left.3.9 \pm 1.3 \mathrm{mg} \cdot \mathrm{kg}^{-1} \cdot \mathrm{min}^{-1} ; p=0.044\right)$. In these 18 patients a significant inverse relationship was found between erythrocyte sodium-lithium countertransport and insulin-mediated glucose disposal $\left(r_{\mathrm{s}}=-0.62 ; p=0.003\right)$. Raised erythrocyte sodium-lithium countertransport appears to be associated with insulin insensitivity in Type 1 diabetes, even in the absence of hyperlipidaemia, hypertension and nephropathy.

Key words: Sodium-lithium countertransport activity, Type 1 (insulin-dependent) diabetes mellitus, insulin-mediated glucose disposal, albuminuria, hyperlipidaemia, hypertension.
It has been suggested that increased erythrocyte sodiumlithium countertransport activity (SLC) may be a genetic marker for essential hypertension [1,2]. The role of elevated SLC as a risk marker for diabetic nephropathy in Type 1 (insulin-dependent) diabetes mellitus is more controversial [3-6]. It is known that environmental factors can affect SLC [7, 8], and an association has previously been shown between SLC and serum lipids in nondiabetic populations [8-11]. Insulin resistance has been associated with high SLC in both essential hypertension [12] and in hypertension complicating Type 1 diabetes [13]. More recently an association has been reported between raised SLC and insulin resistance in a mixed population of normo- and microalbuminuric diabetic patients
[14], but under these circumstances it is difficult to separate the impact of hypertension, hyperlipidaemia and nephropathy on SLC from that of insulin resistance.

In the present study we have therefore examined the relationship between insulin-mediated glucose disposal and SLC in normotensive normolipidaemic normoalbuminuric Type 1 diabetic subjects.

\section{Subjects and methods}

Forty-one (31 male, 10 female) normotensive normoalbuminuric normolipidaemic Type 1 diabetic subjects were selected on the following criteria: continued insulin treatment from the time of diagnosis and post-prandial serum $\mathrm{C}$-peptide concentrations less than 
Table 1. Clinical characteristics of the 41 normoalbuminuric normotensive normolipidaemic Type 1 (insulin-dependent) diabetic subjects and of the matched patients with elevated $\left(>0.40 \mathrm{mmol} \mathrm{Li} \cdot \mathrm{h}^{-1} \cdot 1\right.$ erys $\left.^{-1}\right)$ or normal $\left(<0.40 \mathrm{mmol} \mathrm{Li} \cdot \mathrm{h}^{-1} \cdot 1\right.$ erys $\left.^{-1}\right)$ erythrocyte sodium-lithium countertransport (SLC) activity

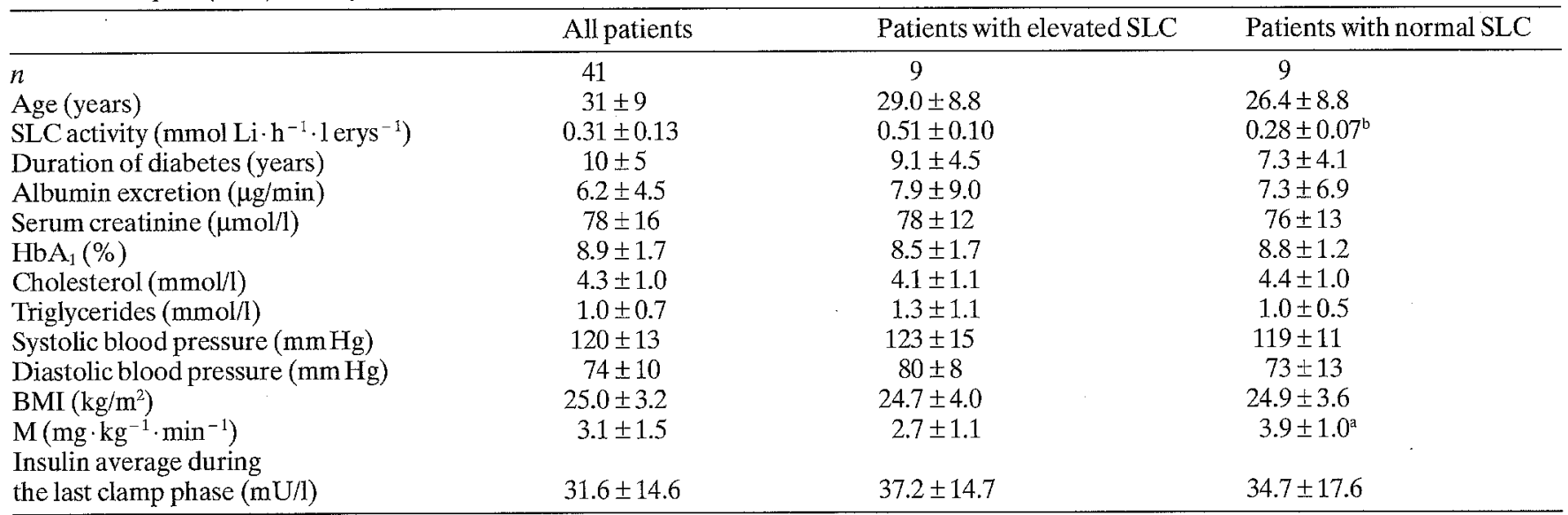

Values shown are mean \pm SD. For comparison between matched patients with elevated or normal SLC ${ }^{a} p=0.044,{ }^{b} p<0.01 ; \mathrm{M}$, Insulin-mediated glucose disposal

$0.40 \mathrm{nmol} / \mathrm{l}$ (below detection limit of the assay in 22 cases), blood pressure less than $160 / 90 \mathrm{~mm} \mathrm{Hg}$, albumin excretion rates less than $30 \mu \mathrm{g} / \mathrm{min}$ in at least two overnight urine collections, and fasting total serum cholesterol and triglycerides less than 6.5 and $2.1 \mathrm{mmol} / 1$, respectively. All patients gave informed consent and the study was approved by the Joint Ethics Committee of the Newcastle Area Health Authority and the University of Newcastle upon Tyne.

All subjects were under the age of 50 years and duration of diabetes ranged from 2 to 23 years (median and mean duration, 10 years). All were treated with 2-4 daily injections of subcutaneous insulin and they had no admissions with diabetic ketoacidosis in the preceding year. The ten women studied were receiving treatment with the low dose combined oestrogen-progesterone oral contraceptive but none of the patients were taking other medication. None of the subjects had symptoms or signs of peripheral neuropathy and all had normal cardiovascular and pupillary tone using age- and genderrelated normative ranges for classification $[15,16]$. Background retinopathy was documented in four cases and one patient had proliferative retinopathy.

Each patient with SLC greater than $0.40 \mathrm{mmol} \mathrm{Li} \cdot \mathrm{h}^{-1} \cdot \mathrm{I}$ erythrocytes $^{-1}\left(\right.$ erys $\left.^{-1}\right)$ was matched to a patient with normal SLC for age, sex, $\mathrm{BMI}, \mathrm{HbA}_{1}$ and duration of diabetes. We selected $0.40 \mathrm{mmol}$ $\mathrm{Li} \cdot \mathrm{h}^{-1} \cdot \mathrm{l}$ erys $^{-1}$ as the upper limit of the reference range since SLC was less than this value in 50 healthy normotensive control subjects in our own laboratory (range $0.10-0.39$ ) and this cut-off value is in keeping with previous findings from other centres [14].

$\mathrm{HbA}_{1}$ was measured by electroendosmosis (Corning Medical, Palo Alto, Calif., USA; reference range 5.0-7.5\%, inter-assay coefficient of variation (CV) $3.7 \%$ ). Whole blood glucose was measured by a glucose oxidase method on a Yellow Springs Analyser (YSI 23AM; Yellow Springs Instruments, Yellow Springs, Ohio, USA; inter-assay CV 1-3\%). Free serum insulin was measured by RIA after precipitation of the antibody-bound insulin with polyethylene glycol [17], using a modified version of the method of Soeldner and Slone [18], with an in-house antibody (inter-assay CV 6.8-7.5\%). Serum C-peptide was measured by RIA using ethanol precipitation [19]. Serum cholesterol was measured by a cholesterol oxidase method on a Cobas Bio fast centrifugal analyser (Roche Products Ltd., Welwyn Garden City, Herts, UK) using a commercial kit (number 725242) supplied by Boehringer Mannheim (Lewes, East Sussex, UK). Between batch CVs ranged between 1.5 to $2.2 \%$ for cholesterol concentrations ranging from 3.9 to $10.3 \mathrm{mmol} / 1$. Serum triglycerides were measured by a lipase-glycerol kinase method without correction for free glycerol on the Cobas Fara centrifugal analyser using a commercial kit (both supplied by Roche Products). Between batch CVs were 3.0 to $3.2 \%$ with triglyceride standards ranging from 2.31 to $3.47 \mathrm{mmol} / \mathrm{l}$. Urinary albumin was measured by sensitive single-antibody RIA with precipitation by polyethylene glycol 6000 [20]. The inter-assay coefficient of variation was $6.9 \%$ at $6 \mu \mathrm{g} / \mathrm{min}$, and the albumin excretion rate from a further single $24 \mathrm{~h}$ urine collection was used in the analyses. Serum creatinine was measured by a multi-channel auto-analyser.

SLC was measured by a method based on that described by Canessa et al. [1] and previously reported in detail [2,8,21]. Venous blood was collected into tubes containing lithium heparin, centrifuged and the erythrocytes were incubated in lithium-loading solution $\left(140 \mathrm{mmol} / 1 \mathrm{LiCl}, 10 \mathrm{mmol} / 1 \mathrm{Li}_{2} \mathrm{CO}_{3}, 10 \mathrm{mmol} / \mathrm{l}\right.$ glucose, $10 \mathrm{mmol} / \mathrm{l}$ Tris-acetate, gassed with $95 \% \quad \mathrm{O}_{2} / 5 \% \mathrm{CO}_{2}, \mathrm{pH} 7.5$, $290 \pm$ (standard error, SE) $2 \mathrm{mosmol} / \mathrm{kg}$ for $1.5 \mathrm{~h}$. The mean intracellular lithium concentration after this loading procedure was $7.36 \pm \mathrm{SE}(0.41) \mathrm{mmol} / \mathrm{l}$. The erythrocytes were then washed once with $\mathrm{MgCl}_{2}(288 \pm(\mathrm{SE}) 1 \mathrm{mosmol} / \mathrm{kg})$ and twice with choline me$\operatorname{dium}\left(139 \mathrm{mmol} / \mathrm{l}\right.$ choline chloride, $1 \mathrm{mmol} / 1 \mathrm{MgCl}_{2}, 10 \mathrm{mmol} / \mathrm{glu}$ cose, $10 \mathrm{mmol} / \mathrm{l}$ Tris-acetate, $\mathrm{pH} 7.4,290 \pm(\mathrm{SE}) 2 \mathrm{mosmol} / \mathrm{kg}$ ). During the final wash the cells were incubated with the choline medium for $10 \mathrm{~min}$ at $37^{\circ} \mathrm{C}$ to allow $\mathrm{pH}$ equilibration so that the mean intracellular $\mathrm{pH}$ was $7.38 \pm(\mathrm{SE}) 0.02$. After the final washing, the packed cell volume of the erythrocytes was measured using a micro-haematocrit and a $0.2 \mathrm{ml}$ portion was incubated in either $1.2 \mathrm{ml}$ of choline medium (as above) or $1.2 \mathrm{ml}$ of sodium medium $(150 \mathrm{mmol} / \mathrm{l} \mathrm{NaCl}$, $1 \mathrm{mmol} / 1 \mathrm{MgCl}_{2}, 10 \mathrm{mmol} / \mathrm{l}$ glucose, $10 \mathrm{mmol} / \mathrm{l}$ Tris-acetate, $10^{-4}$ $\mathrm{mol} / \mathrm{l}$ ouabain, $\mathrm{pH} 7.4,290 \pm(\mathrm{SE}) 2 \mathrm{mosmol} / \mathrm{kg}$ ). Samples were taken after incubation for 1 and $2 \mathrm{~h}$ at $37^{\circ} \mathrm{C}$. After centrifugation of incubation mixtures at $2000 \mathrm{~g}$ for $3 \mathrm{~min}, 200 \mu \mathrm{l}$ of supernatant was mixed with $2 \mathrm{ml}$ of $1.65 \mathrm{mmol} / \mathrm{l} \mathrm{CsCl}$ and the lithium content was measured with an IL943 flame photometer. The sodium-lithium countertransport activity was determined as the difference between lithium efflux from erythrocytes in the sodium and choline media. Osmolality was measured with a Camlab osmometer and adjusted as appropriate. Variability of SLC was assessed in 14 healthy subjects (SLC range $0.10-0.35 \mathrm{mmol} \mathrm{Li} \cdot \mathrm{h}^{-1} \cdot 1$ erys $^{-1}$ ) on at least two occasions within the space of 1 year, and the between batch coefficient of variation was $8.2 \%$.

\section{Euglycaemic clamp}

Patients attended the laboratory following an overnight fast having omitted their morning dose of insulin. Polyethylene catheters were inserted under local anaesthesia with $1 \%$ lignocaine. The first was inserted into an antecubital vein (for infusion of insulin and glucose) and the second retrogradely into a dorsal hand vein and the forearm 


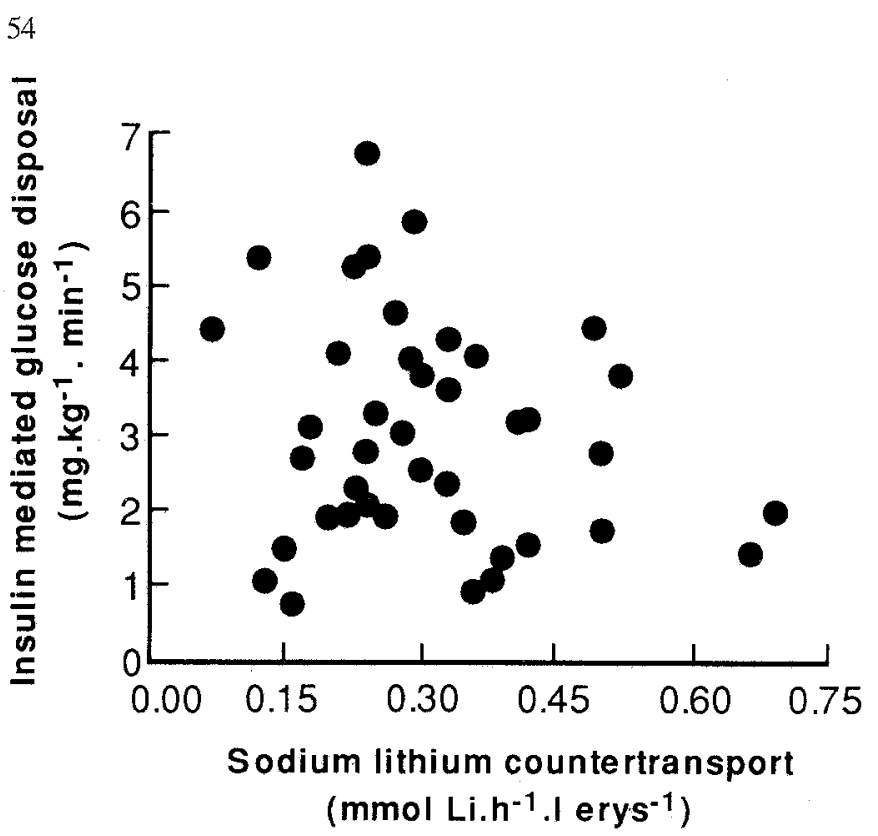

Fig. 1. Relationship between erythrocyte sodium-lithium countertransport activity and insulin-mediated glucose disposal in all 41 Type 1 (insulin-dependent) diabetic subjects. $r_{\mathrm{s}}=-0.14$, NS

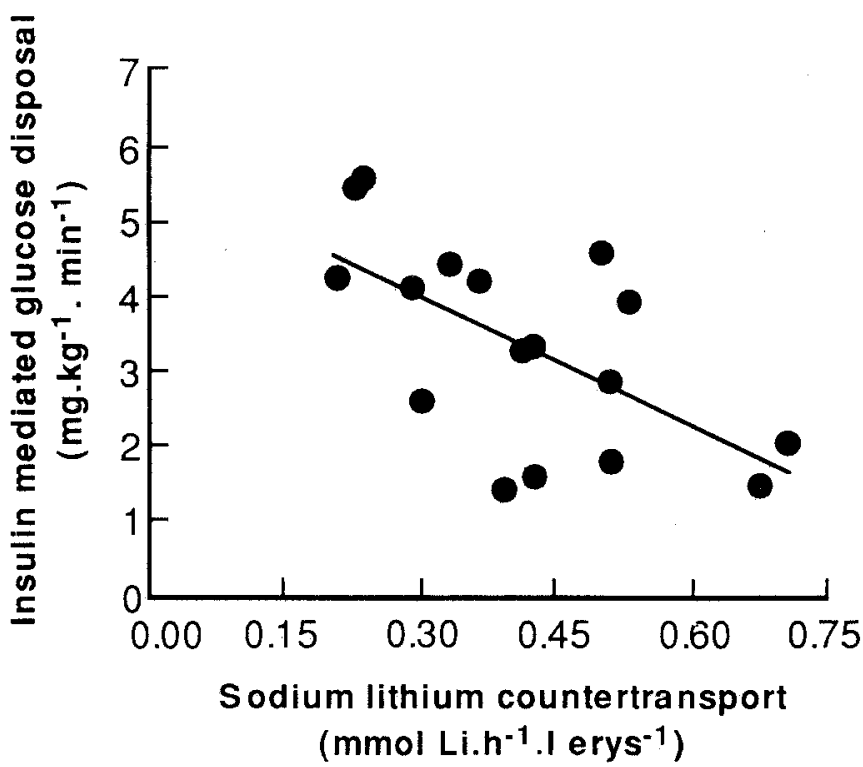

Fig. 2. Relationship between erythrocyte sodium-lithium countertransport activity and insulin-mediated glucose disposal in 18 matched patients with Type 1 (insulin-dependent) diabetes and either elevated or normal erythrocyte sodium-lithium countertransport. $r_{\mathrm{s}}=-0.62, p<0.01$

was warmed in a box set at $55^{\circ} \mathrm{C}$. Samples of arterialised venous blood were taken at $10 \mathrm{~min}$ intervals for blood glucose analyses.

Following a $30 \mathrm{~min}$ period of rest with the catheters in situ, a baseline blood sample was taken for measurement of SLC, $\mathrm{HbA}_{1}$, serum lipids and C-peptide. Thereafter a continuous insulin (Human Actrapid; Novo Nordisk, Crawley, UK) was started (0.015 U . $\left.\mathrm{kg}^{-1} \cdot \mathrm{h}^{-1}\right)$. The aim was to achieve and maintain a blood glucose concentration of $7 \mathrm{mmol} / \mathrm{l}$ whilst avoiding both extreme hyperinsulinaemia and glycosuria. A $20 \%$ glucose infusion was started when the blood glucose level fell below $8 \mathrm{mmol} / \mathrm{l}$ in those cases where the fasting blood glucose was greater than $8 \mathrm{mmol} / \mathrm{l}$ and commenced simultaneously with the insulin infusion in the other cases. After a 2-h equilibration period, the blood glucose was clamped at the target value by the adjustable infusion of the glucose solution.

\section{Catalano et al.: Insulin sensitivity and SLC in Type 1 diabetes}

The insulin-mediated glucose disposal (M) was determined during the last $1-\mathrm{h}$ of the clamp by calculating the amount of glucose infused $\left(\mathrm{mg} \cdot \mathrm{kg}^{-1} \cdot \mathrm{min}^{-1}\right)$ [22]. In all cases, the CV of blood glucose was less than $5 \%$ during the last hour of the clamp (average 2.9 ; range $1.1-4.7 \%$ ). Eight patients showed minor degrees of glycosuria (mean $34 \mu \mathrm{mol} / \mathrm{min}$; range $1-150 \mu \mathrm{mol} / \mathrm{min}$ ) during the clamp and in these the $\mathrm{M}$ was corrected according to the urinary loss of glucose. Intra-individual variability of $M$ was of the order of $20 \%$ in healthy subjects (unpublished data).

\section{Statistical analysis}

Data are expressed as mean \pm SD unless otherwise stated. Possible associations between $M$ and other variables were examined using the Spearman correlation coefficient.

Relationships were tested in the overall population (41 patients) and in the two matched groups separately, and pooled together (18 patients). Comparisons between the nine patients with SLC greater than $0.40 \mathrm{mmol} \mathrm{Li} \cdot \mathrm{h}^{-1} \cdot 1$ erys $^{-1}$ and the matched patients were made by using the $t$-test for unpaired data.

\section{Results}

SLC was on average $0.31 \pm 0.13(0.07-0.69) \mathrm{mmol} \mathrm{Li}$. $\mathrm{h}^{-1} \cdot 1$ erys $^{-1}$. Overall the glucose disposal (M) ranged between 0.78 and $6.77 \mathrm{mg} \cdot \mathrm{kg}^{-1} \cdot \mathrm{min}^{-1}$ (mean $3.1 \pm 1.5 \mathrm{mg} \cdot \mathrm{kg}^{-1} \cdot \mathrm{min}^{-1}$ ). The serum insulin levels during the last hour of the clamp ranged between 9.3 and $75.5 \mathrm{mU} / \mathrm{l}$ (median $28.4 \mathrm{mU} / \mathrm{l}$ ). There was no difference between serum insulin levels of the matched patients with high and normal SLC. SLC overall was not significantly correlated with $\mathrm{M}\left(r_{\mathrm{s}}=-0.14\right)$ (Fig. 1), with the fasting free insulin $\left(r_{\mathrm{s}}=0.09\right)$, fat free mass $\left(r_{s}=-0.10\right)$, BMI $\left(r_{\mathrm{s}}=-0.03\right)$, serum triglycerides $\left(r_{\mathrm{s}}=0.13\right)$, systolic blood pressure $\left(r_{\mathrm{s}}=0.11\right)$, daily insulin dosage $\left(r_{\mathrm{s}}=0.24\right)$, Cpeptide $\left(r_{\mathrm{s}}=0.13\right)$, or duration of diabetes $\left(r_{\mathrm{s}}=-0.06\right)$. There was a weak association between SLC and diastolic blood pressure $\left(r_{s}=0.28 ; p=0.038\right)$. The average insulin levels during the last hour of the clamp were not correlated with simultaneous glucose disposal $\left(r_{\mathrm{s}}=-0.06\right)$.

Those nine patients with SLC greater than $0.40 \mathrm{mmol}$ $\mathrm{Li} \cdot \mathrm{h}^{-1} \cdot 1$ ery $^{-1}\left(0.50 \pm 0.10 \mathrm{mmol} \mathrm{Li} \cdot \mathrm{h}^{-1} \cdot 1\right.$ erys $\left.^{-1}\right)$ were well matched with nine patients with normal SLC $\left(0.28 \pm 0.07 \mathrm{mmol} \mathrm{Li} \cdot \mathrm{h}^{-1} \cdot 1 \mathrm{erys}^{-1}\right)$ for age, gender, BMI, $\mathrm{HbA}_{1}$ and duration of diabetes. When data in these 18 matched patients were considered separately SLC was correlated with $\mathrm{M}\left(r_{\mathrm{s}}=-0.62 ; p<0.01\right)$ (Fig. 2$)$ and patients with SLC greater than $0.40 \mathrm{mmol} \mathrm{Li} \cdot \mathrm{h}^{-1} \cdot 1$ erys ${ }^{-1}$ had a lower $M$ compared to patients with SLC less than $0.40 \mathrm{mmol} \mathrm{Li} \cdot \mathrm{h}^{-1} \cdot 1$ erys $^{-1}(2.7 \pm 1.1$ vs $3.9 \pm 1.3 \mathrm{mg}$. $\left.\mathrm{kg}^{-1} \cdot \min ^{-1}, p=0.044\right)$. In this subgroup SLC was not correlated with serum insulin, fat free mass, blood pressure, serum lipids, insulin dosage, C-peptide or duration of diabetes (data not shown). Separate analysis of the two groups of nine matched subjects did not demonstrate statistically significant differences between the groups (SLC vs $\mathrm{M}, r_{\mathrm{s}}=-0.61$ and $r_{\mathrm{s}}=-0.31$ respectively, in the groups with normal and elevated SLC), reflecting the small sample size and wide confidence intervals of the correlation coefficients. 


\section{Discussion}

Raised SLC has been recently associated with decreased sensitivity to exogenous insulin in patients with essential hypertension [12] and hypertensive or microalbuminuric Type 1 diabetic patients [13,14]. It is however known that both essential hypertension and nephropathy can themselves account for the decreased sensitivity to exogenous insulin [23-25]. In order to assess if raised SLC was associated per se with decreased insulin sensitivity we have tried to avoid possible confounding factors in the present study. For that reason we excluded not only microalbuminuric diabetic patients but also those with hypertension, autonomic neuropathy, hyperlipidaemia or very poor blood glucose control.

In this setting we found that SLC is associated with a degree of insulin insensitivity even in uncomplicated insulin-dependent diabetic patients. However, this relationship is weak. Our Type 1 diabetic patients had a wide range of $M$ values and the relationship was significant only in the case of matched patients. Comparison of matched patients above and below the cut-off point of $0.40 \mathrm{mmol}$ $\mathrm{Li} \cdot \mathrm{h}^{-1} \cdot 1$ erys $^{-1}$ showed a modest but significant difference in the $M$ value. This confirms the suggestion that Type 1 diabetes is characterised by insulin insensitivity of a considerably varying degree [24], and that the independent influence of insulin sensitivity on sodium-lithium countertransport is at best modest.

Several earlier studies described associations between SLC and indices of cardiovascular or renal dysfunction in Type 1 diabetes and essential hypertension [1-6, 11-14, $21,23,26]$. The common inherited nature of elevated SLC in diabetic nephropathy and essential hypertension, however, is the subject of contention, in part due to different methodologies used in measuring SLC activity [3-14]. In addition there is now evidence that the kinetics of SLC activity may be quite different in essential hypertension, uncomplicated and complicated Type 1 diabetes [21, 26, 27]. Irrespective of such concerns, the present association between insulin resistance and increased SLC seems to be genuine, having been recorded previously in patients with essential hypertension [12], hypertensive albuminuric Type 1 diabetic patients $[13,14]$, and in normoglycaemic predominantly normotensive individuals [8]. The association between SLC and insulin sensitivity may be even stronger in patients with essential hypertension and diabetic nephropathy due to the respective additional impact of hypertension and albuminuria on insulin sensitivity and hyperlipidaemia.

In the present study we used a low-dose insulin clamp to enable us to assess both SLC and insulin sensitivity at comparable serum insulin concentrations, thereby avoiding extreme hyperinsulinaemia, which may itself influence SLC [8]. Our target blood glucose was $7.0 \mathrm{mmol} / \mathrm{l}$, and our achieved average insulin level was $37 \mathrm{mU} / \mathrm{l}$, thereby possibly underestimating total insulin resistance. Thus, the study is not strictly comparable to previous assessments of insulin sensitivity and SLC, although in a broad sense the findings are the same.

Different hypotheses have been put forward to explain the inverse relationship between SLC and insulin sensitiv- ity. Elevated SLC could be the consequence of altered ion exchange across cell membranes as a result of resistance to the action of insulin. Alternatively insulin resistance may be secondary to increased SLC through a decrease in the interstitial insulin concentration due to sodium retention and expansion of the sodium pool or impaired insulin transport from blood to interstitium. Insulin insensitivity and raised SLC could, however, have been common end points of an unrelated pathological process which led to altered membrane composition or membrane fluidity or both. An association between membrane fluidity and the insulin receptor concentration on the cell membrane has been previously reported [28].

The suggestion that insulin insensitivity could be a pivotal factor in the pathogenesis of cardiovascular disease in Type 1 diabetes [29] could be particularly relevant when SLC is raised, even before the development of hypertension, hyperlipidaemia or nephropathy.

Acknowledgements. We are grateful to Drs. P.D.Home and R. Taylor for permission to study their patients. Dr. Catalano is a research fellow of the Centro di Fisiologia Clinica del Consiglio Nazionale delle Ricerche, Reggio Calabria, Italy.

\section{References}

1. Canessa M, Adranga N, Solomon HS, Connolly TM, Tosteson DC (1980) Increased red cell sodium-lithium counter-transport in red cells of patients with essential hypertension. N Engl J Med 302: $772-776$

2. Carr SJ, Thomas TH, Wilkinson R (1989) Erythrocyte sodiumlithium countertransport in primary and renal hypertension: relation to family history. Eur J Clin 19: 101-106

3. Krowlewski AS, Canessa M, Warram JH et al. (1988) Predisposition to hypertension and susceptibility to renal disease in insulindependent diabetes mellitus. N Engl J Med 318: 140-145

4. Mangili R, Bending JJ, Scott G, Li LK, Gupta A, Viberti G (1988) Increased sodium-lithium countertransport activity in red cells of patients with insulin-dependent diabetes and nephropathy. N Engl J Med 318: 146-150

5. Elving LD, Wetzel JFM, De Pont JJHHM, Berden JHM (1992) Is increased erythrocyte sodium-lithium countertransport a useful marker for diabetic nephropathy? Kidney Int 41: 862-871

6. Jensen JS, Mathiesen ER, Nørgaard K et al. (1990) Increased blood pressure and erythrocyte sodium/lithium countertransport activity are not inherited in diabetic nephropathy. Diabetologia 33: 619-624

7. Adranga N, Chang S, Morey M, Williams R (1985) Effects of exercise on cation transport in human red cells. Hypertension 7: 132-139

8. Winocour PH, Thomas TH, Brown L, Laker MF, Wilkinson R, Alberti KGMM (1992) Serum triglyceride and insulin levels are associated with erythrocyte sodium-lithium countertransport activity in normoglycaemic individuals. Clin Chim Acta 208: 193203

9. Corrocher R, Steinmayr M, Ruzzenente O et al. (1985) Elevation of red cell Na-Li CT in hyperlipidaemias. Life Sci 36: 649-655

10. Hunt S, Williams RR, Smith JB, Ash KO (1986) Associations of three erythrocyte cation transport systems with plasma lipids in Utah subjects. Hypertension 8: 30-36

11. Carr SJ, Thomas TH, Laker MF, Wilkinson R (1990) Elevated sodium-lithium countertransport: a familial marker of hyperlipidaemia and hypertension. J Hypertens 8: 139-146

12. Doria A, Fioretto P, Avogaro A et al. (1991) Insulin rèsistance is associated with high sodium-lithium countertransport in essential hypertension. Am J Physiol261: E684-E691 
13. Trevisan R, Nosadini R, Fioretto P et al. (1992) Clustering of risk factors in hypertensive insulin-dependent diabetics with high sodium-lithium countertransport. Kidney Int 41: 855-861

14. Lopes De Faria J, Jones SL, Macdonald F, Chambers J, Mattock MB, Viberti GC (1992) Sodium-lithium countertransport activity and insulin resistance in normotensive IDDM patients. Diabetes 41: 610-615

15. O'Brien IAD, O'Hare JP, Corrall RJM (1986) Heart rate variability in healthy subjects: effects of age and the derivation of normal ranges for tests of autonomic function. $\mathrm{Br}$ Heart $\mathrm{J} 55$ : 348-354

16. Smith SA, Dewhurst RR (1986) A simple diagnostic test for pupillary abnormality in diabetes autonomic neuropathy. Diabetic Med 3: 38-41

17. Hanning I, Home PD, Alberti KGMM (1985) Measurement of free insulin concentrations: the influence of the timing of extraction of insulin antibodies. Diabetologia 28: 831-835

18. Soeldner JS, Slone D (1965) Critical variables in the radioimmunoassay of serum insulin using the double antibody technique. Diabetes 14: 771-779

19. Heding LG (1975) Radioimmunological determination of human C-peptide in serum. Diabetologia 11:541-548

20. Christensen C, Ørskov C (1984) Rapid screening PEG radioimmunoassay for quantification of pathological microalbuminuria. Diabetic Nephropathy 3: 92-97

21. Rutherford PA, Thomas TH, Carr SJ, Taylor R, Wilkinson R (1992) Kinetics of sodium-lithium countertransport activity in patients with uncomplicated Type 1 diabetes. Clin Sci 82: 291299

22. DeFronzo RA, Tobin JD, Andres R (1979) Glucose clamp technique: a method for quantifying insulin secretion and resistance. Am J Physiology 237: E214-E223
23. Jones LS, Trevisan R, Tariq T et al. (1990) Sodium-lithium countertransport in microalbuminuric insulin-dependent diabetic patients. Hypertension 15: 570-575

24. Yki-Jarvinen H, Koivisto VA (1986) Natural course of insulin resistance in type 1 diabetes. New Engl J Med 315: 224-230

25. Ferrannini E, Buzzigoli G, Bonadonna R et al. (1987) Insulin resistance in essential hypertension. N Engl J Med 317: 350-357

26. Rutherford PA, Thomas TH, Carr SJ, Taylor R, Wilkinson R (1992) Changes in erythrocyte sodium-lithium countertransport kinetics in diabetic nephropathy. Clin Sci 82: 301-307

27. Rutherford PA, Thomas TH, Wilkinson R (1992) Erythrocyte sodium-lithium countertransport: clinically useful, pathophysiologically instructive or just phenomenology? Clin Sci 82: 341-352

28. Gould RJ, Ginsberg BH, Spector AA (1982) Effect of lipid composition on the properties of the reconstituted insulin receptor. J Biol Chem 257: 477-482

29. Martin FIR, Hopper JL (1987) The relationship of acute insulin sensitivity to the progression of vascular disease in long-term type 1 (insulin-dependent) diabetes mellitus. Diabetologia 30: $149-153$

Received: 30 June 1992

and in revised form: 8 September 1992

Dr. P.H. Winocour

Department of Medicine

University of Newcastle upon Tyne

The Medical School

Framlington Place

Newcastle upon Tyne NE2 4HH

UK 